\title{
PENGARUH CAPITAL ADEQUACY RATIO (CAR) DAN LOAN TO DEPOSIT RATIO (LDR) TERHADAP PROFITABILITAS RETURN ON ASSET (ROA) PT BANK MANDIRI TBK
}

\author{
Ade Ratna Sari \\ Rizky Kurnia Fajar
}

\begin{abstract}
ABSTRAK
Tujuan dari penelitian ini adalah:mengetahui Pengaruh Capital Adequacy Ratio (CAR) dan Loan To Deposit Ratio (LDR) Terhadap Return On Assets (ROA) pada Bank Mandiri yang terdaftar diBEI dengan periode pengamatan tahun 2007 - 2016. Serta guna mengetahui pengaruh secara persial maupun simultan terhadap profitabilitas Return OnAsset (ROA) PT.Bank Mandiri Tbk periode 2007-2016.

Metode penelitian yang digunakan oleh peneliti adalah menggunakan metode dekskriptif dan metode verifikatif dengan pendekatan kuantitatif dengan

menggunakan analisis Regresi Berganda.Populasi ini adalah laporan keuangan PT Bank Mandiri Tbk periode2007-20016. Analisis data yang digunakan dalam penelitian ini menggunakan analisis Deskriptif,Uji Asumsi Klasik meliputi :Uji Normalitas,Uji Multikolinearitas,Uji Autokorelasi,Uji Hesteroskedastisitas dan Uji Hipotesis meliputi : Uji Statistik T, Uji F, Koefesien Desterminasi, Uji Regresi Linear Berganda.Penelitian ini menggunakan bantuan program aplikasi SPSS22.

Hasil pada penelitian ini menyatakan bahwa Capital Adequacy Ratio (CAR) sebagai variabel bebas (tidak berpengaruh secara persial terhadap Profitabilitas (ROA) PT.BankMandiri, Tbk.Hal tersebut dibuktikan dengan hasil perhitungan uji t dengan hasil perhitungan statistikuji $=-3,768$, sedangkan $=1,894$, <dengan taraf signifikans $i 0,007<0,05$, maka Ho ditolak dan diterima ,sehingga dapat dikatakan Capital Adequacy Ratio (CAR) tidak berpengaruh secara persial terhadap profitabilitas (ROA).Sedangkan Loan Deposit Ratio (LDR) berpengaruh secara persial terhadap Profitabilitas (ROA) PT. Bank Mandiri, Tbk. Hasil penelitian ini didapat setelah melakukan perhitungan uji persial (uji t)dengan uji $=1,847$ sedangkan $=1.894$, $>$ dengan taraf signifikansi 0,107>0,05, maka Ho diterima dan ditolak.sehingga dapat dikatan Loan To Deposit Ratio (LDR)berpengaruh positif namun tidak signifikan terhadap profitabilitas (ROA). Namun dihitung secara simultan (bersama-sama) Capital Adequacy Ratio (CAR) dan Loan To Deposit Ratio berpengaruh terhadap Profitabilitas (ROA) pada PT.Bank Mandiri, Tbk. Kesimpulan ini berdasarkan hasil uji signifikan simultan (uji statistik F)yang diperoleh hasil sebesa $\mathrm{r} 8,386>4,74$ dengan taraf signifikansi $0,014<0,05$,maka Ho ditolak dan di terima.Hal tersebut menunjukan bahwa variabel independen berpengaruh secara simultan terhadap variabel dependen,hipotesis yang diajukan yaitu CAR dan LDR berpengaruh simultan terhadap ROA.
\end{abstract}

\section{Kata Kunci: CAR, LDRdan ROA}

\section{ABSTRAC}

The purpose of this research is: to know the Influence of Capital Adequacy Ratio (CAR) and Loan To Deposit Ratio (LDR) to Return On Assets (ROA) at Bank Mandiri listed on BEI with observation period year 2007 - 2016. And to know influence or simultaneously to profitability Return On Assets (ROA) of PT Bank Mandiri Tbk period 2007-2016.

The research method used by the researcher is using descriptive method and verification method with quantitative approach by using multiple regression analysis. This population is the financial statements of PT Bank Mandiri Tbk 2007-20016 period. Data analysis used in this research use Descriptive analysis, Classic Assumption Test include: Normality Test, Multicolinearity Test, Autocorrelation Test, Hesteroskedasticity Test and Hypothesis Testing include: T Test Statistic, F 


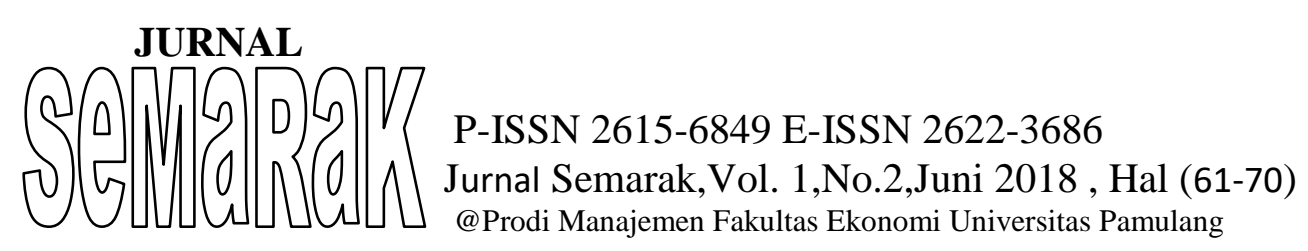

Test, Coefficient of Destermination, Multiple Linear Regression Test. This research uses the help of SPSS22 application program.

The result of this research stated that Capital Adequacy Ratio (CAR) as independent variable (does not have an effect on the profitability of PT Bank Mandiri Tbk.) It is proved by the result of $t$ test with statistic test $=-3,768$, while $=1.894$, <with the significance level of $0.007<0.05$, then Ho is rejected and accepted, so it can be said Capital Adequacy Ratio (CAR) has no effect persial on profitability (ROA) .While Loan Deposit Ratio (LDR) effect persial on Profitability (ROA) of PT Bank Mandiri, Tbk The result of this research is obtained after doing the calculation of the test of persial (ujit) with test $=1,847$ whereas $=1.894$, > with significance level $0,107>0,05$, Ho is accepted and rejected so that it can be categorized Loan To Deposit Ratio (LDR) has positive but not significant effect on profitability (ROA) but calculated simultaneously (together) Capital Adequacy Ratio (C AR) and Loan To Deposit Ratio effect on Profitability (ROA) at PT.Bank Mandiri, Tbk. This conclusion is based on the result of simultaneous significant test (F statistical test) obtained by result of 8,386> 4,74 with significance level $0,014<0,05$, hence Ho is rejected and accepted. It shows that the independent variables simultaneously affect the dependent variable, the proposed hypothesis is CAR and LDR simultaneous effect on ROA.

\section{Keyword: CAR, LDRdan ROA}

\section{PENDAHULUAN}

\section{A. Latar Belakang Masalah}

Terjadinya krisis utang yang terjadi di Eropa tahun 1997 menyebabkan keadaan ekonomi secara global menjadi tidak menentu beberapa industri keuangan yang ada di Eropa dan AS. Berdasarkan data dari Federal Deposit Insurance Corporation (FDIC) menunjukkan bahwa AS telah menutup beberapa banknya ditahun 2011 sebanyak 64 bank, tahun 2010 sebanyak 157 bank dan tahun 2009 sebanyak 140 bank (vibiznews, 2011). Hal ini tentu akan berdampak pula pada kegiatan operasional perbankan di indonesia dimana fungsi intermediasi bank dalam penyaluran kredit ini menjadi terhambat karena melemahnya nilai tukar rupiah terhadap nilai tukar dolar Amerika Serikat akibatnya operasional perbankan di indonesia menjadi dilikuidasi dan mengalami pembekuan yang berkepanjangan.

Sektor perbankan pada saat ini sudah mulai mengalami perkembangan yang cukup signifikan, dalam proses perkembangannya tersebut perbankan selalu terus berusaha untuk meningkatkan kinerja keuangannya. Perkembangan persaingan dunia perbankan yang sangat pesat serta tingkat kompleksitas yang tinggi dapat berpengaruh terhadap performa suatu bank. Permasalahan - permasalahan perbankan di Indonesia antara lain disebabkan oleh depresiasi rupiah, peningkatan suku bunga sertifikat Bank Indonesia (SBI), manajemen tidak professional, bank tidak mampu memenuhi kewajibannya sehingga menyebabkan meningkatnya kredit bermasalah yang akhirnya membuat kinerja menurun dan kesehatan bank memburuk. Bank Umum Swasta Nasional sebagai salah satu bentuk lembaga perbankan di Indonesia yang tidak luput dari masalah tersebut di atas, dituntut untuk tetap bertahan hidup dan berkembang didalam mencapai tujuannya.

Analisis ROA mengukur kemampuan kinerja perusahaan dalam menghasilkan laba dengan menggunakan total aset (kekayaan) yang dipunyai 
perusahaan setelah disesuaikan dengan biaya - biaya untuk mendanai aset tersebut Yusti (2011:28). ROA penting bagi bank karena ROA digunakan untuk mengukur efektivitas perusahaan dalam menghasilkan keuntungan dengan memanfaatkan aktiva yang dimilikinya. ROA merupakan rasio antara laba sebelum pajak terhadap total aset. Semakin besar ROA maka menunjukkan kinerja perusahaan yang semakin membaik. Rasio - rasio yang mempengaruhi ROA adalah : CAR, LDR, NPL, BOPO, NIM, (Kasmir, 2012;201, Munawir, 2007;91, Harahap, 2010;305, dalam Yusti, 2011:28). Bank Indonesia juga lebih mengutamakan nilai profitabilitas suatu bank yang diukur dengan ROA dibandingkan dengan ROE karena Bank Indonesia lebih mengutamakan nilai profitabilitas suatu bank yang diukur dengan aset yang dananya sebagian besar berasal dari simpanan masyarakat sehingga ROA lebih mewakili dalam mengukur tingkat profitabilitas bank.

Sedangkan analisis CAR Menurut Dendawijaya (2009:121) mendefinisikan CAR adalah rasio yang memperlihatkan seberapa jauh seluruh aktiva bank yang mengandung risiko ( kredit penyertaan, surat berharga, tagihan pada bank lain) untuk dibiayai dari dana modal bank itu sendiri. Jika CAR suatu bank meningkat maka ROA akan meningkat juga, dimana standar besarnya CAR menurut Bank of International Settlements secara umum adalah $8 \%$ dari Aktiva Tertimbang Menurut Risiko (ATMR).

Semakin tinggi Loan to Deposit Ratio (LDR) maka laba bank akan semakin meningkat, dengan meningkatnya laba bank maka kinerja bank juga meningkat. Penelitian mengenai Loan to Deposit Ratio (LDR) yang dilakukan oleh Ahmad Buyung Nusantara (2009:110 ) memperlihatkan hasil bahwa Loan to Deposit Ratio
(LDR) berpengaruh positif dan signifikan terhadap Return on Asset (ROA).

CAR (Capital Adequacy Ratio) merupakan rasio kewajiban pemenuhan modal minimum (KPMM). Terlihat pada table 1.1 bahwa kemampuan dalam menyediakan dana untuk keperluan pengembangan usaha serta menampung kemungkinan resiko kerugian pada tahun 2007 sebesar $21.10 \%$ dan tahun 2008 mengalami penurunan sebesar $15.70 \%$ pada tahun 2009 mengalami penurunan sebesar $15.60 \%$, pada tahun 2010 kembali mengalami penurunan sebesar $14.70 \%$, pada tahun 2011 mengalami peningkatan sebesar $17.20 \%$, namun pada tahun 2012 mengalami penurunan sebesar $15.48 \%$ dan pada tahun 2013 terjadi penurunan sebesar $14.93 \%$, pada tahun 2014 mengalami peningkatan sebesar $16.60 \%$ dan tahun 2015 sebesar $18.60 \%$ hingga pada tahun 2016 mengalami peningkatan sebesar $21.36 \%$.

Dalam upaya menyelesaikan permasalahan diatas,dibutuhkan peran serta CAR,karena hubungan antara CAR dan ROA suatu bank adalah positif dimana jika CAR suatu bank meningkat maka ROA akan meningkat juga dimana standar besarnya CAR sebesar $8 \%$.

Berdasarkan data laporan Bank Mandiri Tbk, tahun 20072016,terlihat bahwa pertumbuhan LDR dari tahun ketahun mengalami peningkatan,namun besaran LDR Bank Mandiri masih dibawah standar dengan rata-rata $73.22 \%$, sementara yang diisyaratkan adalah $110 \%$. Ini menjadi permasalahan serius yang dihadapi oleh Bank Mandiri Tbk.dimana sangat wajar jika kemampuan bank dalam menghasilkan laba belum maksimal,mengingat kemampuan 


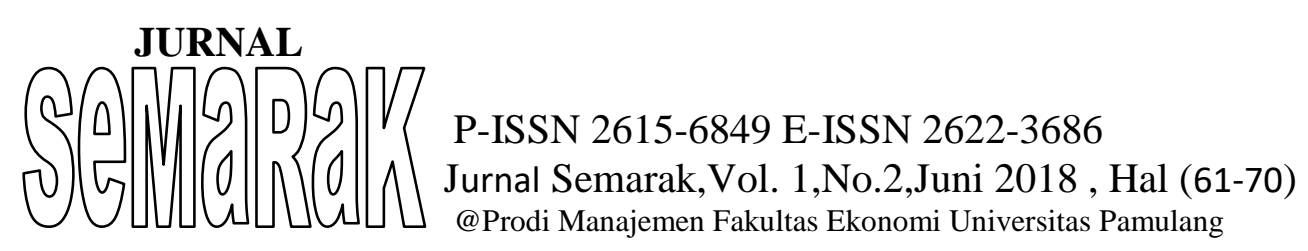

bank dalam mengoperasikan usahanya masih sangat rendah.

Berdasarkan penjelasan diatas,penulis tertarik untuk melakukan penelitianmengenai permasalahan yang terjadi pada pengaruh CAR dan LDR terhadap profitabilitas ROApada Bank Mandiri Tbk tahun 2007-2016.

\section{Batasan Masalah}

Banyaknya masalah diatas, maka penulis melakukan pembatasan terhadap masalah-masalah yang hanya menjadi focus dalam penelitian ini, yakni masalah yang berkaitan dengan judul penelitian ,yaitu :

1. Profabilitas (ROA)

Menurut Kasmi

Kemampuan perusahaan untuk memperoleh pendapatan dalam kegiatan operasi perusahaan dengan memanfaatkan aktiva yang dimilikinya.

2. Loan to Deposit Ratio (LDR)

Menurut

Harahap

(2013:319)Merupakan perbandingan antara total kredit yang diberikan dengan total dana pihak ketiga (DPK) yang dapat di himpun oleh bank.

3. Capital Adequacy Ratio (CAR)

Menurut Lukman Dendawijaya (2009:121) CAR adalah rasio yang memperlihatkan seberapa jauh seluruh aktiva bank yang mengandung resiko ikut dibiayai dari dana modal sendiri bank, disamping memperoleh dana-dana dari sumber sumber diluar bank.

4. Tempat

Objek penelitian ini dilakukan pada PT Bank Mandiri. Tbk

5. Waktu

Penelitian ini dilaksanakan dari bulan April 2017 hingga Juli 2017.

\section{Rumusan Masalah}

1.

2.
3. Adakah pengaruh Capital Adequacy Ratio terhadap Return On Asset PT Bank Mandiri ,Tbk ?

4. Adakah pengaruh Loan To Deposit Ratio terhadap Return On Asset PT Bank Mandiri,Tbk ?

5. Adakah pengaruh Capital Adequacy Ratio dan Loan to Deposit Ratio secara bersama-sama terhadap Return On Asset PT Bank Mandiri, Tbk?

\section{E. Tujuan Penelitian}

1. Untuk mengetahui adanya pengaruh Capital Adequacy Ratio terhadap Return On Asset PT Bank Mandiri, Tbk.

2. Untuk mengetahui adanya pengaruh Loan to Deposit Ratio terhadap Return On Asset PT Bank Mandiri, Tbk.

3. Untuk mengetahui adanya pengaruh Capital Adequacy Ratio dan Loan to Deposit Ratio secara bersama-sama terhadap Retrun On Asset PT Bank Mandiri Tbk.

\section{G. Kerangka Berpikir}

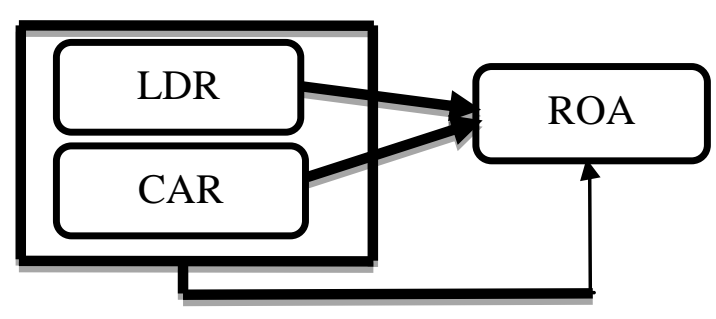

$\mathrm{H} 3$

\section{Gambar 1.1 \\ Pengaruh LDR dan CAR terhadap Profitabilitas (ROA)}

H. Hipotesis Penelitian

1. Diduga terdapat pengaruh LDR terhadap ROA PT Bank Mandiri, Tbk.

2. Diduga terdapat pengaruh CAR terhadap ROA PT Bank Mandiri, Tbk.

3. Diduga terdapat pengaruh LDR dan CAR secara bersama-sama terhadap ROA PT Bank Mandiri, Tbk.

Selanjutnya hipotesis dirumuskan ke dalam persamaan statistik uji regresi yang kemudian 


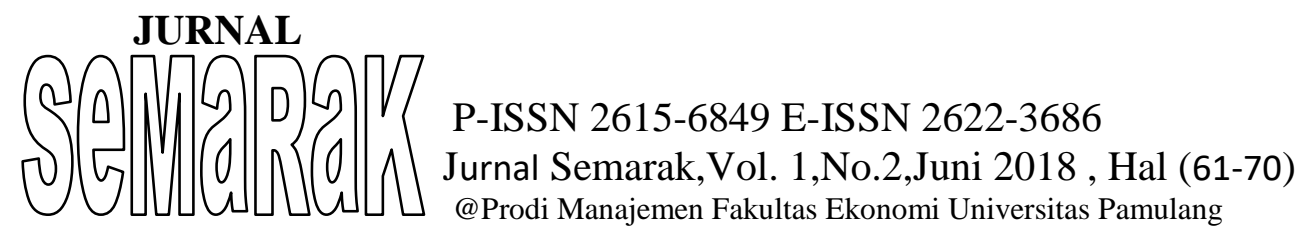

akan dianalisis dan dibahas, berikut persamaan hipotesis statistik :

1. Ha1 $: y>0$

Artinya: Ada pengaruh LDR terhadap ROA PT Bank Mandiri, Tbk.

Ho1 $: y=0$

Artinya: Tidak ada pengaruh LDR terhadap ROA PT Bank Mandiri, Tbk.

2. Ha2 : $y>0$

Artinya: Ada pengaruh CAR terhadap ROA PT Bank Mandiri, Tbk.

$\mathrm{Ho} 2: \beta \mathrm{x}_{2} y=0$

Artinya: Tidak ada pengaruh CAR terhadap ROA PT Bank Mandiri, Tbk.

3. Ha3 : $y>0$

Artinya: Ada pengaruh LDR dan CAR secara bersama-sama terhadap ROA PT Bank Mandiri, Tbk.

Ho3 $: y=0$

Artinya: Tidak ada pengaruh LDR dan CAR secara bersama-sama terhadap ROA PT Bank Mandiri, Tbk.

\section{TINJAUAN PUSTAKA}

\section{A. Manajemen}

1. Pengertian Manajemen

Menurut ( Robbin dan Coulter,2007;8 ) manajemen adalah proses pengordinasian kegiatankegiatan pengerjaan sehingga pekerjaan tersebut terlesaikan secara efesien dan efektif dengan melalui orang lain. Kata efesiensi dapat diartikan sebagai mendapatkan output terbesar dengan input yang sangat kecil, sementara efektifitas dapat diartikan pada penyelesaian kegiatan - kegiatan sehingga sasaran organisasi dapat tercapai.

Manajemen dipandang
sebagai upaya atau proses
pencapaian tujuan $\begin{array}{r}\text { dengan } \\ \text { menggunakan keahlian oranglain }\end{array}$
Azhar Susanto $(2007: 68)$

\section{B. Manajemen Keuangan}

1. PengertianManajemenKeuangan

Keuangan (finance) meliputi tiga area yang saling berkaitan diantaranya : 1 . Pasar finansial (pasar uang dan pasar modal), 2. Investasi sekuritas dan 3. Manajemen keuangan. Manajemen keuangan adalah suatu kegiatan perencanaan, penganggaran, pemeriksaan, pengelolaan, pengendalian, pencarian dan penyimpanan dana yang dimiliki oleh suatu organisasi atau perusahaan. Selain itu manajemen juga bisa diartikan sebagai manajemen terhadap fungsi-fungsi keuangan. (Hanafi, $2010: 1)$.

\section{A. Laporan Keuangan}

1. Pengertian Laporan Keuangan

Laporan keuangan dapat dengan jelas memperlihatkan gambaran kondisi keuangan dari perusahaan. Laporan keuangan yang merupakan hasil dari kegiatan operasi normal perusahaan akan memberikan informasi keuangan yang berguna bagi entitas-entitas di dalam perusahaan itu sendiri maupun entitas-entitas di luar perusahaan.

\section{B. Lembaga Keuangan Bank}

1. Pengertian Bank

Menurut Undang-Undang Republik Indonesia No.10 Tahun 1998 pasal 1 ayat 2 tentang perbankan dijelaskan bahwa "Bank adalah badan usaha yang menghimpun dana dari masyarakat dalam bentuk simpanan dan menyalurkannya kepada masyarakat dalam bentuk kredit atau bentuk-bentuk lainnya dalam rangka meningkatkan taraf hidup rakyat banyak".

E. Retrun On Assets (ROA)

Menurut Kasmir (2013:196), profitabilitas Return On Assets (ROA) 


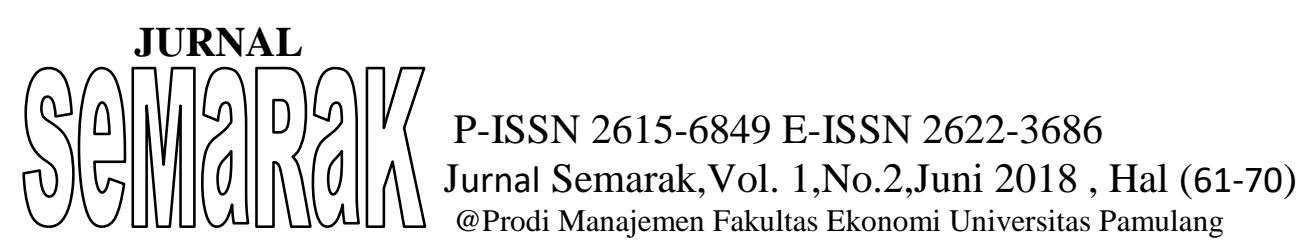

merupakan rasio yang digunakan untuk menilai kemampuan perusahaan dalam mencari keuntungan dengan memanfaatkan aktiva yang dimilikinya.

F. Loan To Deposit Ratio (LDR)

Menurut Harahap (2013:319), Loan to Deposit Ratio merupakan rasio yang menunjukkan seberapa besar pinjaman yang diberikan di danai oleh dana pihak ketiga.

\section{METODOLOGI PENELITIAN}

\section{A. Tempat, Waktu, Ruang Lingkup} Penelitian, dan Desain Penelitian

1. Tempat

Objek penelitian ini adalah PT. Bank Mandiri, Tbk, yang beralamat di Jalan Jenderal Gatot Subroto Kav. 36-38 Jakarta 12190 INDONESIA.

2. Waktu

Penelitian ini dilaksanakan dari bulan April 2017 hingga Juli 2017

3. Ruang Lingkup Penelitian

Penelitian ini termasuk dalam ruang lingkup penelitian Manajemen Keuangan, yang secara Khusus menelaah pengaruh Capital Adequacy Ratio (CAR) danLoan To Deposit Ratio (LDR) Terhadap Profitabilitas Retrun On Asset (ROA) Pada PT. Bank Mandiri, Tbk Tahun 20072016.

\section{A. Metode Penelitian}

Metode penelitian yang digunakan dalam penelitian ini adalah metode dengan pendekatan deskriptif asosiatif. Dimana pengertian penelitian deskriptif menurut Sugiyono dalam Aldi Wandra (2013:54) Penelitian deskriptif adalah penelitian yang dilakukan untuk mengetahui nilai variabel mandiri, baik satu variabel atau lebih (independen) tanpa membuat perbandingan, atau menghubungkan dengan variabel yang lain. Sedangkan penelitian asosiatif menurut Sugiyono dalam Aldi Wandra (2013:55) Penelitian asosiatif merupakan penelitian yang bertujuan untuk mengetahui hubungan antara dua variabel atau lebih.

\section{B. Metode Analisis Data}

\section{Statistik Deskriptif}

2. Pengujian Asumsi Klasik

a. Uji Normalitas

1). Analisis Grafik

2). Analisis Statistik
a. Uji Multikolinieritas
b. Uji Autokorelasi
c. Uji Heteroskedastisitas

2. Uji Hipotesis

a. Koefisien Determinasi atau

Koefisien Korelasi (Adj R. Square)

a. Uji F (Uji Statistik Simultan)

$$
\begin{aligned}
F_{h}= & \frac{R^{2} /(k-1)}{\left(1-R^{2}\right) /(n-k)} \\
& \text { Dimana: } \\
\mathrm{R} & =\text { Koefisien korelasi ganda } \\
\mathrm{K} & =\text { Jumlah variabel } \\
\mathrm{N} & =\text { Jumlah sampel }
\end{aligned}
$$

a. Uji t ( uji persial)

$$
t=\frac{r_{p} \sqrt{n-3}}{\sqrt{1-r_{p}^{2}}}
$$

Dimana:

$\mathrm{r}_{\mathrm{p}}=$ Korelasi parsial yang ditemukan $\mathrm{n}=$ Jumlah sampel

\section{b. Analisis Regresi Linier Berganda}

$$
\mathrm{Y}=\mathrm{a}+b_{1} X_{1}+b_{2} X_{2}+\mathrm{e}
$$

Keterangan:

$\mathrm{Y}=$ Variabel terpengaruh (Profitabilitas)

$a=$ Konstanta

$\mathrm{X}_{1}=$ Variabel indikator ke-1 Capital Adequacy Ratio

$\mathrm{X}_{2}=$ Variabel indikator ke-2 Loan To

Deposit Ratio

$\mathrm{b}_{1}=$ Koefisien regresi prediktor Capital Adequacy Ratio

$\mathrm{b}_{2}=$ Koefisien regresi prediktor Loan To

Deposit Ratio

$\mathrm{e}=$ Error Time 


\section{JURNAL}

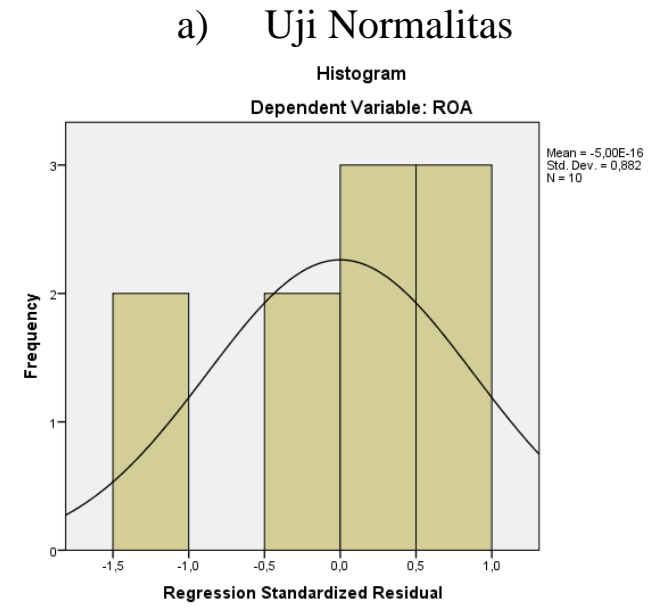

b) Uji Multikolinearitas

\section{Hasil Uji Multikolinearitas}

\begin{tabular}{|c|c|c|c|c|c|}
\hline \multicolumn{6}{|l|}{ Coefficients $^{a}$} \\
\hline \multirow[b]{2}{*}{ Model } & \multicolumn{3}{|c|}{ Correlations } & \multicolumn{2}{|c|}{ Collinearity Statistics } \\
\hline & $\begin{array}{l}\text { Zero- } \\
\text { order }\end{array}$ & Partial & Part & Tolerance & VIF \\
\hline $1 \quad$ (Constant) & & & & & \\
\hline CAR &,- 750 &,- 818 &,- 773 & ,996 & 1,004 \\
\hline LDR & 329 & ,572 & 379 & 996 & 1,004 \\
\hline
\end{tabular}

c) Uji Autokorelasi

Hasil Uji Autokorelasi

Model Summary
\begin{tabular}{|l|c|r|r|r|r|}
\hline Model & $\mathrm{R}$ & $\begin{array}{c}\mathrm{R} \\
\text { Square }\end{array}$ & $\begin{array}{c}\text { Adjusted } \\
\text { R Square }\end{array}$ & $\begin{array}{c}\text { Std. Error } \\
\text { of the } \\
\text { Estimate }\end{array}$ & $\begin{array}{r}\text { Durbin- } \\
\text { Watson }\end{array}$ \\
\hline 1 &, $840^{\mathrm{a}}$ &, 706 &, 621 & 36,83232 & 1,834 \\
\hline
\end{tabular}
a. Predictors: (Constant), LDR, CAR
b. Dependent Variable: ROA

d) Uji Hesteroskedastisitas

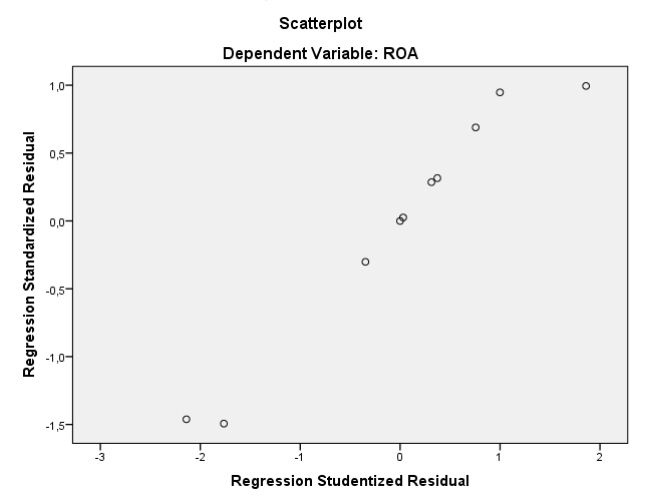

1. Uji Hipotesis

a. Uji Statistik T (uji parsial) Uji T (Uji Parsial)

\begin{tabular}{|c|c|c|c|c|c|}
\hline \multirow[b]{2}{*}{ Model } & \multicolumn{2}{|c|}{$\begin{array}{l}\text { Unstandardized } \\
\text { Coefficients }\end{array}$} & \multirow{2}{*}{$\begin{array}{c}\begin{array}{c}\text { Standardized } \\
\text { Coefficients }\end{array} \\
\text { Beta } \\
\end{array}$} & \multirow[b]{2}{*}{$t$} & \multirow[b]{2}{*}{ Sig. } \\
\hline & B & $\begin{array}{l}\text { Std. } \\
\text { Error }\end{array}$ & & & \\
\hline $\begin{array}{ll}1 & \text { (Constant) }\end{array}$ & 489,039 & 111,542 & & 4,384 &, 003 \\
\hline CAR &,- 189 &, 050 &,- 774 & $-3,768$ & ,007 \\
\hline LDR & 019 & 010 & 380 & 1.847 & 107 \\
\hline
\end{tabular}

a) Hasil Uji Hipotesis pengaruh CAR (X1) Terhadap ROA (Y)

Hipotesis pertama yang diajukan menyatakan bahwa CAR berpengaruh negatif terhadap ROA. Dapat dilihat bahwa nilai $t_{\text {hitung }}$ untuk variabel CAR sebesar -3,768. Nilai ini akan dibandingkan dengan $t_{\text {tabel }}$ sebesar 1,894 pada tabel distribusi $t$. Dimana $t_{\text {hitung }}-3,768<t_{\text {tabel }} 1,894$ dan nilai signifikasi lebih kecil dari pada Std. Error yakni 0,007 < 0,05 jadi kesimpulannya menunjukkan bahwa Ho diterima dan Ha ditolak, sehingga dapat disimpulkan bahwa persial hipotesis ini menyatakan bahwa CAR tidak berpengaruh terhadap ROA.

b) Hasil Uji Hipotesis pengaruh LDR (X2) Terhadap ROA (Y)

Hasil hipotesis menunjukkan bahwa LDR berpengaruh positif terhadap ROA. Dapat dilihat bahwa nilai $t_{\text {hitung }}$ untuk LDR sebesar 1,847. Nilai ini akan dibandingkan dengan $t_{\text {tabel }}$ sebesar 1,894 pada tabel distribusi t. Dimana $\mathrm{t}_{\text {hitung }}=1,847<\mathrm{t}_{\text {tabel }}=$ 1,894 dan nilai signifikasi 0,107 $>$ 0,05. Jadi kesimpulannya menunjukan bahwa Ho ditolak dan Ha diterima, sehingga LDR berpengaruh positif namun tidak signifikan terhadap ROA. 
a. Uji F (Uji Simultan) Uji F (Uji Simultan)

penilai tingkat kesehatan bank dimana tingkat kesehatan bank ANOVA $^{\mathrm{a}}$ memperlihatkan kondisi_kineria keuangan

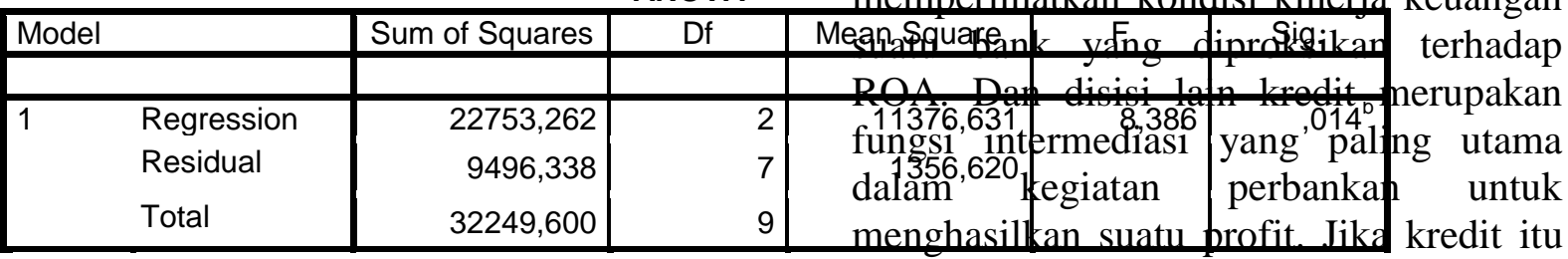

a. Dependent Variable: ROA

b. Predictors: (Constant), LDR, CAR

Pada tabel diatas dapat dilihat bahwa hasil Uji f menunjukkan nilai $F_{\text {hitung }}$ sebesar 8,386 sedangkan $\mathrm{F}_{\text {tabel }}$ sebesar 4,74 dengan nilai signifikasi sebesar $0,014<0,05$, maka $\mathrm{H}_{\mathrm{O}}$ ditolak dan $\mathrm{H}_{1}$ diterima. Hal tersebut menunjukkan bahwa variabel independen berpengaruh secara simultan terhadap variabel dependen, hipotesis yang diajukan yaitu CAR dan LDR berpengaruh simultan terhadap ROA diterima. Artinya setiap perubahan yang terjadi pada variabel independen yaitu CAR dan LDR secara simultan atau bersama-sama akan berpengaruh pada ROA PT Bank Mandiri.

b. Koefisien Determinasi (Adjusted $\mathbf{R}^{\mathbf{2}}$ ) Hasil Uji Koefisien Determinasi Model Summary

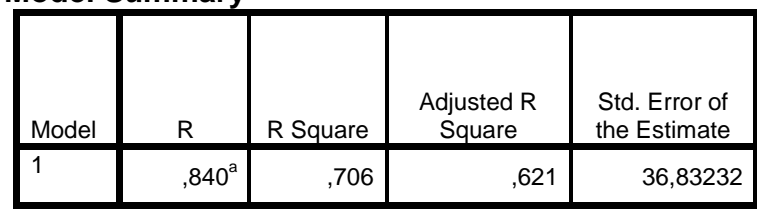

a. Predictors: (Constant), LDR, CAR

b. Dependent Variable: ROA

Tabel menunjukkan koefisien korelasi (R) dan koefisien determinasi (R Square). Nilai $\mathrm{R}$ menerangkan tingkat hubungan antar variabel-variabel independen $(\mathrm{X})$ dengan variabel dependen (Y). Dari hasil olahan data diperoleh nilai koefisien korelasi sebesar 0,840 atau sama dengan $84 \%$ artinya hubungan antar variabel $\mathrm{X}$ (CAR, LDR) Terhadap variabel Y (ROA) dalam kategori sangat kuat sekitar $84 \%$ variabel CAR, LDR berpengaruh terhadap ROA. Sekitar $16 \%$ dipengaruhi faktor-faktor lain diluar model. Hal ini disebabkan variabel CAR dan LDR termasuk indikator (CAMELS) mengalami hambatan (tingkat LDR menurun) maka tingkat profit (ROA) juga akan menurun, maka ROA juga akan mengalami perubahan.

$\mathrm{R}$ Square menjelaskan seberapa besar variasi $\mathrm{Y}$ yang disebabkan oleh $\mathrm{X}$, dari hasil perhitungan diperoleh nilai $R^{2}$ sebesar 0,706 atau $70,6 \%$ artinya $70,6 \%$ ROA dipengaruhi oleh kedua variabel CAR dan LDR. Dan sisanya sekitar 29,4\% dipengaruhi oleh faktor-faktor lain diluar model. Hal ini dikarenakan indikator penilai tingkat kesehatan bank tidak hanya terdiri dari kedua variabel $\mathrm{X}$ (CAR, dan LDR) tetapi ada juga indikator lainnya seperti nilai perusahaan, harga saham, ukuran perusahaan, jasa bank non kredit, manajemen bank dan lainnya.

\section{e. Uji Regresi Linier Berganda} Uji Regresi Linier Berganda

\section{Coefficients $^{\mathrm{a}}$}

\begin{tabular}{|c|c|c|c|c|c|}
\hline \multirow[b]{2}{*}{ Model } & \multicolumn{2}{|c|}{$\begin{array}{l}\text { Unstandardized } \\
\text { Coefficients }\end{array}$} & $\begin{array}{c}\text { Standardiz } \\
\text { ed } \\
\text { Coefficient } \\
\text { s }\end{array}$ & \multirow[b]{2}{*}{$\mathrm{T}$} & \multirow[b]{2}{*}{ Sig. } \\
\hline & $\mathrm{B}$ & Std. Error & Beta & & \\
\hline $\begin{array}{ll}1 & \text { (Consta } \\
& \text { nt) }\end{array}$ & 489,039 & 111,542 & & 4,384 & ,003 \\
\hline CAR & -189 & ,050 & -,774 & $-3,768$ & ,007 \\
\hline LDR & ,019 & ,010 & ,380 & 1,847 & 107 \\
\hline
\end{tabular}

a. Dependent Variable: ROA

Dari hasil output diatas diperoleh nilai B sebesar 489,039 nilai CAR sebesar -0,189 dan nilai LDR sebesar 0,019. Dengan demikian maka dapat dibentuk persamaan regresi linier berganda sebagai berikut:

$$
\mathrm{Y}=489,039-0,189\left(\mathrm{X}_{1}\right)+0,019\left(\mathrm{X}_{2}\right)+\mathrm{e}
$$

Berdasarkan model regresi linier berganda diatas, maka hasil regresi linier berganda dapat dijelaskan sebagai berikut:

1. Dari persamaan regresi linier berganda diatas, diketahui mempunyai konstanta 


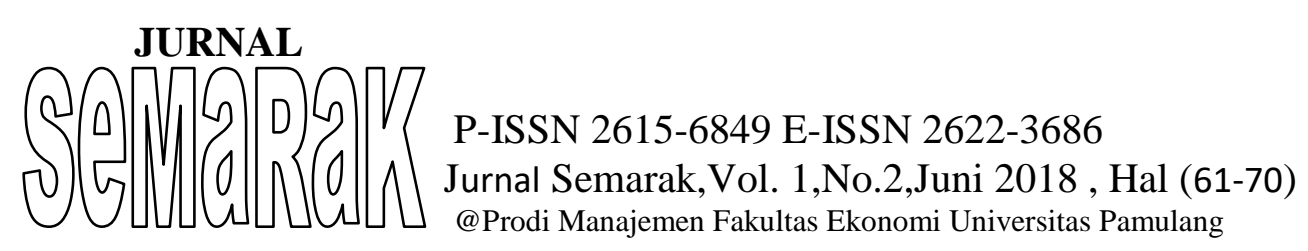

sebesar 489,039. Sehingga besaran konstanta menunjukkan bahwa jika variabel-variabel independen (CAR dan LDR) diasumsikan konstanta maka variabel dependen yaitu ROA akan berubah sebesar $489,039 \%$.

2. Variabel CAR memiliki koefisiensi bertanda negatif sebesar $-0,189$. Hal ini berarti menunjukkan bahwa jika CAR meningkat satu persen (1\%) maka ROA akan berubah sebesar -0,189\%.

3. Variabel LDR mempunyai koefisien sebesar 0,019 hal ini berarti menunjukkan bahwa jika LDR meningkat $1 \%$ maka ROA akan berubah sebesar $0,019 \%$.

\section{KESIMPULAN DAN SARAN}

\section{A. KESIMPULAN}

1. Berdasarkan hasil penelitian yang telah dilakukan diketahui bahwa Capital Adequacy Ratio (CAR) sebagai variabel bebas $\left(X_{1}\right)$ berpengaruh negatif secara persial terhadap Profitabilitas (ROA) PT. Bank Mandiri, Tbk. Hal tersebut dibuktikan dengan hasil perhitungan uji $t$ dengan menggunakan program SPSS versi 22 dengan hasil perhitungan statistik uji $t_{\text {hitung }}=-3,768$, sedangkan $t_{\text {tabel }}=1,894$, $t_{\text {hitung }}>t_{\text {tabel }}$ dengan taraf signifikansi $0,007<0,05$, maka Ho diterima dan $H_{a}$ ditolak, sehingga dapat disimpulkan bahwa secara persial hipotesis ini menyatakan bahwa CAR tidak berpengaruh terhadap ROA.

2. Berdasarkan hasil penelitian yang telah dilakukan diketahui bahwa Loan To Deposit Ratio (LDR) tidak berpengaruh secara persial terhadap Profitabilitas (ROA) PT. Bank Mandiri, Tbk. Hasil penelitian ini didapat setelah

\section{B. SARAN}

3. melakukan perhitungan uji persial (uji t) dengan uji $t_{\text {hitung }}=1,847$ sedangkan $t_{\text {tabel }}=1.894$, , $t_{\text {hitung }}<t_{\text {tabel }}$ dengan taraf signifikansi 0,107>0,05, maka Ho diterima dan $H_{1}$ ditolak. sehingga dapat dikatan Loan To Deposit Ratio (LDR) berpengaruh positif namun tidak signifikan terhadap profitabilitas (ROA).

4. Berdasarkan hasil penelitian yang telah dilakukan diketahui bahwa Return On Assets (ROA) dihitung Secara simultan (bersama-sama) Capital Adequacy Ratio (CAR) dan Loan To Deposit Ratio berpengaruh terhadap Profitabilitas (ROA) pada PT. Bank Mandiri, Tbk. Kesimpulan ini berdasarkan hasil uji signifikan simultan (uji statistik F) yang dilakukan penulis dengan menggunakan program SPSS versi 22 diperoleh hasil $F_{\text {hitung }}$ sebesar 8,386>4,74 dengan taraf signifikansi $0,014<$ 0,05, maka Ho ditolak dan $H_{a}$ diterima. Hal tersebut menunjukan bahwa variabel independen berpengaruh secara simultan terhadap variabel dependen, hipotesis yang diajukan yaitu CAR dan LDR berpengaruh simultan terhadap ROA.

1. Bank Mandiri diharapkan meningkatkan pengelolaan aset agar tidak terjadi kerugian yang dapat menurunkan Return On Assets (ROA) dan pada akhirnya akan menurunkan Capital Adequacy Ratio (CAR).

2. Bagi pihak emiten (manajemen Perusahaan) merujuk pada penelitian ini, diharapkan selalu menjaga tingkat kecukupan modalnya sehingga pada akhirnya dengan tercukupinya 


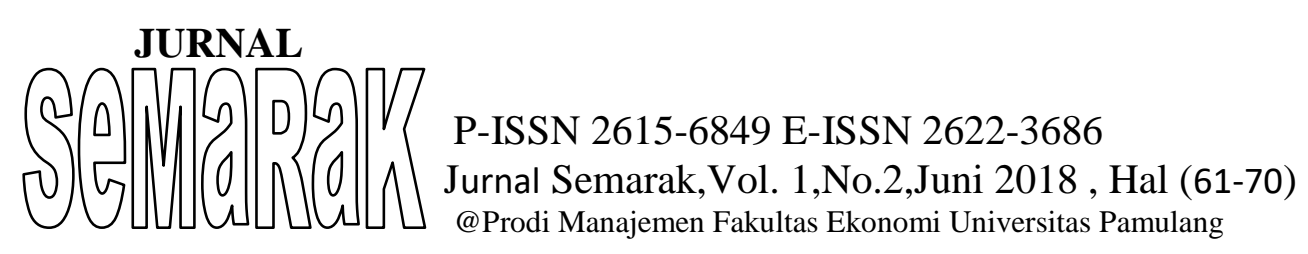

3. tingkat kecukupan modal, kinerja keuangan bank tersebut akan meningkat.

4. Bagi pihak investor rasio Capital Adequacy Ratio (CAR) dapat dijadikan sebagai bahan pertimbangan untuk menentukan strategi investasinya. karena semakin besar rasio Capital Adequacy Ratio (CAR) suatu bank maka semakin tinggi pula laba yang berarti semakin tinggi juga kinerja keuangan pada bank tersebut.

\section{DAFTAR PUSTAKA}

Dendawijaya, Lukman. (2009). ManajemenPerbankan, Jakarta : PT. Ghalia Indonesia.

Duwi Priyatno. (2012). Analisis Korelasi, Regresi, dan Multivariate dengan SPSS. Yogyakarta : Gava Media.

Fahmi, Irham. (2012). Analisis Laporan Keuangan. Cetakan ke-2. Bandumg : Alfabeta.

Ghozali, Imam. (2011). Aplikasi Analisis Multivariate Dengan Program SPSS. Semarang : Universitas Diponegoro.

Harahap, Sofyan Syafri. (2013). Analisis Kritis Laporan Keuangan. Jakarta : PT. Ghalia Indonesia.

(2009). "Analisis Kritis Atas Laporan Keuangan". Jakarta : PT. Raja Grafindo Persada.

(2010). "Analisis Kritis Atas Laporan Keuangan". Jakarta : PT. Rajawali Persada.

Hasibuan, Malayu S.P. (2009). Manajemen Dasar, Pengertian, dan Masalah. (Edisi Revisi). : Jakarta : PT. Bumi Aksara.

Husein Umar. (2009). Metode Penelitian. Jakarta : PT. Salemba Empat.

Ikatan Akuntan Indonesia.(2009).
Pernyataan Standar Akuntansi

Keuangan 16. Jakarta : PT. Salemba Empat.

Kasmir.(2010) Analisa Laporan Keuangan. Edisi ke 3. Jakarta : Rajawali Pers. (2012). "Manajemen Perbankan".
Jakarta : Rajawali Pers.
(2013). "Manajemen Perbankan" .
Jakarta : Rajawali Pers.
(2014) "Analisis Laporan
Keuangan". Jakarta: Rajawali Pers.
Martono dan Agus Harjito.(2010)
Manajemen Keuangan (Edisi 3).
Yogyakarta : Ekonisia.
Mudrajad, Kuncoro dan Suhardjono. (2011). Manajemen Perbankan Teori dan Aplikasi. Yogyakarta: BPFE.

Munawir. Analisis Laporan Keuangan. Edisi 4. Penerbit: Liberty. Yogyakarta. 2010

Noor, Juliansyah. Metodologi Penelitian: Skripsi, Tesis, Disertasi, dan Karya Ilmiah. Penerbit: PT. Kencana Prenada Media Group. Jakartra. 2011

"Metodologi Penelitian “. Penerbit: PT. Kencana Prenada Media Group. Jakarta. 2011

Sartono, Agus. Manajemen Keuangan Teori dan Aplikasi. (Edisi IV). Penerbit: BPFE. Yogyakarta. 2010

Solihin, Ismail. Pengantar Manajemen. Penerbit: PT. Erlangga. Jakarta. 2009

“Pengantar Manajemen". Penerbit: PT. Erlangga. Jakarta. 2010

Sugiyono. Metode Penelitian Kuantitatif dan Kualitatif. Penerbit: Cv.Alfabeta, Bandung. 2009

" Metode Penelitian Pendidikan Pendekatan Kuantitatif, Kualitatif, dan $R \& D$ “. Penerbit: Cv.Alfabeta. Bandung. 2010

"Memahami Penelitian Kualitatif ". Penerbit: Cv.Alfabeta. bandung. 2012

Sutrisno Edy Dr, Msi. Manajemen Sumber Daya Manusia, Penerbit: PT. Kencana Prenada Media Group. Jakarta. 2010

Sutrisno. Manajemen Keuangan Teori, Konsep dan Aplikasi (Edisi 8). Penerbit : Ekonisia. Yogyakarta. 2012 